\title{
Media and the theatralization of power: an interview with Peter Burke
}

\begin{abstract}
Aline STRELOW ${ }^{1}$
Abstract:

Peter Burke holds the title of Professor Emeritus at the University of Cambridge, and a doctoral degree from the University of Oxford. He has worked in the universities of Sussex, Essex, and Princeton. In Brazil, he was a visiting professor at the Institute of Advanced Studies of the University of São Paulo in the 1990's. Burke wrote dozens of books, among which: Popular culture in Early Modern Europe (1978), The Renaissance (1987), The fabrication of Louis XIV (1994), A social history of knowledge (2000), and A social history of the media (2002). In this interview, he talks about several topics related to Communication: media and the theatralization of power, from Louis XIV to nowadays; persuasion and manipulation; image analysis and media convergence, and more. The interview was recorded on June 9th 2017, in São Paulo, the day after Peter Burke delivered the opening lecture at the XI Encontro Nacional de História da Mídia - Alcar 2017.
\end{abstract}

Keywords:

Media history. Media manipulation. Media and power. Media convergence.

\section{A mídia e a teatralização do poder: entrevista com Peter Burke}

Resumo:

Peter Burke é professor emérito da Universidade de Cambridge e doutor pela Universidade de Oxford. Atuou também nas universidades de Sussex, Essex e Princeton. No Brasil, foi professor visitante do Instituto de Estudos Avançados da Universidade de São Paulo, na década de1990. É autor de dezenas de livros, entre eles: Cultura popular na Idade Moderna (1978), O Renascimento italiano (1987), A fabricação do rei (1994), Uma história social do conhecimento (2000) e Uma história social da mídia (2002). Nesta entrevista, ele fala sobre diversos assuntos relacionados à Comunicação: a mídia e a teatralização do poder, desde Louis XIV até os dias atuais; persuasão e manipulação; análise de imagens e convergência midiática, entre outros. A entrevista foi realizada no dia 09 de junho de 2017, em São Paulo, um dia após Peter Burke realizar a conferência de abertura do XI Encontro Nacional de História da Mídia - Alcar 2017.

Palavras-chave:

História da Mídia. Manipulação midiática. Mídia e poder. Convergência midiática.

\section{Los medios y lateatralizacióndel poder: entrevista con Peter Burke}

\section{Resumen:}

Peter Burke es profesor emérito de laUniversidad de Cambridge y doctorenlaUniversidad de Oxford. Tambiénactuóenlas universidades de Sussex, Essex y Princeton. En Brasil, fueprofesor visitante del Instituto de EstudiosAvanzados de laUniversidad de São Paulo, enla década de 1990. Es autor de decenas de libros, entre ellos: Cultura popular enlaEdad Moderna (1978), El Renacimiento italiano(1987), La fabricacióndelrey (1994), Una historia social delconocimiento (2000) y Una historia social de losmedios (2002) ). En esta entrevista, élhabla sobre diversos asuntos relacionados alaComunicación: losmedios y lateatralizacióndel poder, desde Luis XIV hasta losdíasactuales; persuasión y manipulación; elanálisis de imágenes y laconvergencia mediática, entre otros. La entrevista fue realizada eldía 9 de junio de 2017 enSao Paulo, undíadespués de la conferencia de apertura del XI Encontro Nacional de História da Mídia Alcar 2017.

' Professor of the Communication and Librarianship College of Universidade Federal do Rio Grande do Sul (Fabico/UFRGS). Post-doctorate in Communication by Universidade Metodista de São Paulo (UMESP). Doctorand Master in Communication by Pontifícia Universidade Católica do Rio Grande do Sul (PUCRS). Coordinator of the Communication History research group at Fabico/UFRGS. Editor of Revista Brasileira de História da Mídia (RBHM). E-mail: alinestrelow@ terra.com.br. 
Palabras clave:

Historia de losMedios. Manipulación mediática. Medios y poder. Convergenciamediática.

Professor Peter Burke, the author of reference works for Communication and Media History researchers, delivered the opening speech at the XI Encontro Nacional de História da Mídia - Alcar 2017, in São Paulo. In his lecture, he spoke about media manipulation under a historical perspective, discussing concepts such as post-truth and fake news. In this interview, taken on June 9th 2017, a day after the event, he talks about several topics associated to Communications: media and the theatralization of power, from Louis XIV to nowadays; persuasion and manipulation; image analysis and media convergence, and more.

Peter Burke holds the title of Professor Emeritus at the University of Cambridge, and a doctoral degree from the University of Oxford. He has worked in the universities of Sussex, Essex, and Princeton. In Brazil, he was a visiting professor at the Institute for Advanced Studies of the University of São Paulo in the 1990's. Burke wrote dozens of books, among which: Popular Culture in Early Modern Europe (1978), The Renaissance (1987), The Fabrication of Louis XIV(1994), A Social History of Knowledge (2000), and A Social History of the Media (2002).

Question: In your book The Fabrication of Louis XIV, you analyze the construction of the king's public image by employing, among the analysis concepts, the concept of theatralization of power, which was gaining new aspects by the time the book came out and has transformed greatly in the last decade, with the growth and popularization of digital social networks. How do you see this theatralization nowadays? What parallels can we trace with Louis XIV?

Peter Burke: That's a good question, I need to think, but the theatralization in politics is very old. Louis is simply a good and well documented example. Of course this process continues. Maybe now the public is more aware of the theatre than it used to be. It's difficult to tell, because people did not do research on the public reaction to this theatralizationin earlier centuries, we don't know what ordinary people thought, whether the king was putting on an act, whether he was himself. So what's new now, well... there are more images more rapidly available, and every now and then we have a good image of what goes on behind the scenes. Sometimes because this tape recorder is left on - remember the famous case, George Bush thinking it was switched off - and so you 
suddenly get a glimpse of what goes on behind the stage. And this happens more often with the leaks and the moles that operate today. So that's a bit different, I mean, there were attempts to unmask Louis, but people could say "oh, that's just counterpropaganda, the Dutch are making it up". It's only very rarely that you get a witness who will say something about theatralization from inside. There's a wonderful source I quoted, I think I quoted it in the book, an Italian nobleman is in Versailles because anybody respectably dressed could go into Versailles at any time - and he's standing in the main gallery, that would be the Gallery of Mirrors, and the door opens and the king steps out of his private parts of the palace, and as he steps out, he arranges his face to be the king's face. And he's seen doing this in that split second by the Italian nobleman, and then suddenly you get that glimpse, which is so rare for the XVII century, but much more common now.

Question: In the book, you reflect on the importance of rituals in politics, and consider that physical impressions sometimes have more impact in audiences than language. What are the main rituals in Louis XIV and in current politics?

Peter Burke: The main rituals in which he engaged were getting up and going to bed, very simple acts, but they were elaborated into this grand lever $d u$ roi and coucher duroi, where he had to be handed different items of clothing by different nobles, and it had to be done so the most important noble in the room would have the right to hand him something. Sometimes there was disagreement, and people would almost be fighting to be the person to give the king some article of clothing. It would be interesting to know what Louis thought about all this, but that's not documented. But Louis XV, we know that after he was formally put to bed with the coucher $d u$ roi, everybody went to bed, he got up again, and then he went to play cards with his wife and went to bed when he wanted. So that gives a sense he felt this all was rather uncomfortable, but they wouldn't get rid of it because this helped diffuse the image of the powerful king with everybody serving him.

Question:One of the book's many inputs refers to the rather restricted group of Louis XIV's watchers and listeners. You declare that the propagation of rhetoric studies among the elite at the time made them quite aware of the persuasion techniques employed, maybe more than most of us are today. Can we thus conclude that 
persuasion, and even manipulation, techniques have become more sophisticated and, at the same time, we became even less prepared to interpret them critically?

Peter Burke: Now you can leak a tape, or videotape, instead of simply leaking a document. But I don't know, does that make so much difference? It has to be somebody on the inside illegally making public something on the inside. But this is a very old habit. My favorite examples come from Venice in the XVII century. In Venice, the ambassadors abroad wrote confidential reports, and they came home and they read them aloud to the senate, and then these reports were lodged in a special archive, and to keep them more secret, the keeper of the archive... they chose somebody who couldn't read and write. So that was safe. All the same, in Rome and other places you could buy copies of these confidential reports. So somebody, we don't know who, was leaking them. And when a Venetian ambassador came to England, and I think his secretary had a day off, and he went to Oxford, and went to Bodleian Library because he liked books.And he was amazed, he found manuscript copies of the secret documents and there's a letter which records his shock. So this is his published work I'm talking about, he thinks that every now and then the leaks were not unofficial. That is, the Venetian government decided that they would leak some information. So you've got two kinds of leak: the ones the government supports and the ones that it didn't want but somebody else is doing it. So I can't think of anything more sophisticated than the government leaking things and pretending that they weren't official. So in that sense I was wondering whether there's any room for a more sophisticated approach today.

Question: Do you think that we are prepared to interpret these messages critically, these messages around power, do you think the public is prepared to read critically these messages?

Peter Burke: That's a difficult question because, of course, the public includes lots of people who are very different from one another, some very critical and some less critical. What might be new today is simply the sheer volume of the leaks. I mean, when Wikileaks operates, suddenly thousands of documents appear, rather than just one or two at a time. And then it's very difficult to react to all this. Ordinary members of the public will only see excerpts from just a few of the many documents that are leaked. And you could say it's a new danger when there's so much being leaked, and the possibility that so much will be leaked, how do you come upon that... confidential 
negotiations, how can you be sure that when you're whispering in somebody's ear, that it won't all going to be in the press the next week. And we need confidential negotiations. Things have to be a secret from the public for a time, until the deal is done. Even in a democracy, you can't publish each moment of negotiations because it makes negotiating impossible. And that is a problem that is really raised by Wikileaks, it's not just a question of embarrassing people, but it's a question of how do we continue to do things. There has to be a backstage, and it's not wicked to have a backstage, maybe it's wicked to keep some things from the public, but not everything. People would have said that in the XVII century, they talked about arcana imperii, the secrets of state. Maybe they wanted to keep too much secret, but now maybe too much is open.

Question:You take an interesting interpretation of Erving Goffman to approach the fabrication of Louis XIV's image from a dramaturgical perspective. The idea of front and back regions are among the concepts you used. We have the feeling that, nowadays, the back regions have transitioned to the front, with leaders' intimacy being exposed, often deliberately, to establish identification. However, the reading of Louis XIV shows that even his daily actions were theatricalized and followed by a small group, or, at least, by his servants. Waking up, eating, going to bed... How do you identify changes in this process, and where do these changes stand before the development of means of communication?

Peter Burke: I think it's a gradual process, and not a rapid one, and it goes back longer than people think. Around the time of Louis XIV, although not so much in France, there was a new genre of publication called "the secret history". Usually this was anonymous, or under a pseudonym, and these texts would claim to reveal the secrets of a particular court, usually. Sometimes it would be the secrets of a religious order, especially the Jesuits, but the favorite topic would be to reveal the secrets of the court. Sometimes it was fiction, but the fiction was transparently about, for example, the court of Queen Anne, in England. So, in that sense, that's the ancestor of Wikileaks. They print documents which may not be true documents, but maybe fiction, because they want to give what Roland Barthes calls the "reality effect", and they did this quite well. So, even though there are not spectacular examples from the reign of Louis XIV, there are from the reign of his successors in the XVIII century, and in XVIII century England. 
Actually, a famous English writer of fiction, Daniel Defoe, he also wrote non-fiction, including two or three books with the title Secret History. And this is all linked to the conflict between the two parties, the Whigs and the Tories, and he was hired by one side, but then somebody else was hired by the other side and they wrote a secret history of The Secret History, which was to expose... So I think this is a level of sophistication which is not going to be very easy to do better than that, though I'm sure people do as well as that. I suppose they're more professional now, that is, Daniel Defoe was parttime novelist, part-time travel writer, and part-time in the pay of a political party. But now these men in the shadows I was talking about last night ${ }^{2}$, it's a full time job. They're trained for it and they normally stay in it. These publicity advisors, they don't go into politics on their own account, at least not usually. They stick to this job. So that shows only that we live in an age of increasing specialization, but I don't think the principles change.

Question: In the book Eyewitnessing, you point out the importance of considering the meaning of images towards different audiences. Image analysis must be followed by studies on what the cultural consumer builds with these images, as Certeau also said. How do you see this preoccupation in communications and media history studies, concerning image studies performed in this field?

Peter Burke:I think the crucial thing is how the viewers respond in different periods. I belong to the pre-television generation, in the sense that my parents did not buy a television till I was already an adult. When I taught a course about the image's historical source in Cambridge, I used, sometimes, to test the perceptions of the students, because I would show an image, and then I wouldn't tell them anything about the context, and I would ask them to say what they thought about it. And it was interesting that they very often had very sharp observations. They noticed all sorts of details, and I began to wonder whether the television generation, or any subsequent generation, deals with images all the time, in a way that we didn't. We were more, that was more of a text generation, because all you saw at school was texts. Nobody gave you pictures to analyze. So, whether that would increase what they would notice, they would be... of course, an image can work on people without their knowing it works on them. So, I suppose one has to distinguish these two aspects of the reception of images: the almost

2The interview was held the day after the lecture by Peter Burke at the XI Encontro Nacional de História da Mídia - Alcar 2017. 
unconscious reception, and you can train people to be critical and to make what was not conscious, conscious. And there's this, the learning, the habit of reading images, which if you... looking at images all the time, in your spare time you're watching a screen or something, maybe you become more skilled in reading. And of course the same students are not as good with texts as my generation was, there's always a price for something. It's not that they don't know more or less that we did at their age, but they know different things.

Question:In the same book, you observed that historians tended to treat images as mere illustrations, reproducing them without comment, or citing conclusions the author reached through other means. After the book you talked that it's changed a little. To what do you ascribe this, since we already live immersed in images of all kinds? How do you see changes in research in this area since the book came out?

Peter Burke:I think, probably, there is a greater consciousness of the use of images, both for understanding the past, and then for presenting the past when you are writing about it. And yes, the number of serious illustrations, not only in books, but - I think is particularly revealing - articles in professional journals. Maybe the English Historical Review, which is a bit conservative, doesn't do this yet, but Past \& Present, which is the most important historical journal in Britain, you look at the issues from the 1950's to now, and you see an increasing number of illustrations, and they would only accept illustrations if they were part of the argument. They're not in the business of selling the magazine because it's got nice pictures. So I think, yes. I was complaining about all the people in the historical profession, but as time goes on, this complaint is less realistic, I'm happy to say, people, the younger ones in particular. Almost all the $\mathrm{PhDs} I$ 've examined in the last ten years have illustrations. This would never have been the case even in the 1980's.

Question: As a historian in this field, how do you assess the current setting of media convergence? How do you see the role of prints (books, newspapers, magazines etc.) in the next decades?

Peter Burke: In a word, downsizing. That is, I don't believe in the death of the book, or anything like this, but in this competition between media, then books, printed books, are taking a smaller place. I suppose, obviously, in the field of newspapers - because the newspapers are reducing the number of copies, paper copies, and sometimes they are 
giving up paper copies. But the different media continue to coexist, even if the balance between them is changing. In this way, I'm comforted by the historical example: when printing was invented, that did not mean that nothing was circulating in manuscript. A lot continued to circulate in manuscript, and gradually a division of labor developed, so that certain kinds of information circulated in manuscript: more confidential information; or nobles who felt that if they published a printed book, people would think that they were getting money for it, and that was embarrassing. Poems would only circulate in manuscript. Only after their death could somebody print the poems of some famous English writers, Sir Philip Sydney, or somebody like that. So I think now we are now establishing a division of labor between online and paper. Books are also getting smaller, because the publishers are realizing that there are few people with the patience to read a long book. And this is the question now, on whether the younger generation would be able to read in the traditional sense, or only to scan. I'm not so pessimistic because I think that it's possible to use your eyes on print in different ways, you can read at different speeds. I used to taunt my university students that they shouldn't always read things at the same speed. You need rapid reading when you are trying to dig some information out of a massive material, other times you need a very slow reading because you need to take in every nuance of a document, and there's ordinary reading in-between. I think it's perfectly possible for people both to scan and to read. But they won't, maybe, do that if people don't teach them, and they need to do these different things. So this is, yet again, something to do in the schools. I think what people should teach in schools: how to think, how to read, how to write. Of course, a bit of information. But these techniques, which are so basic, they come before everything else, I think.

Question:You are a scholar of Gilberto Freyre's work, having already dedicated books and essays to it. Concerning Brazilian media history, Freyre was a pioneer in the study of newspaper advertisements (The slave in Brazilian newspaper ads in the XIX century). How did you come upon him? What is Freyre's main input, in your opinion?

Peter Burke: When I was still a student at Oxford I discovered the work of Fernand Braudel, a famous big book on the Mediterranean. And in the footnotes of Braudel's book there was a reference to somebody called Gilberto Freyre, who had written a study called Casa Grande \&Senzala. I was learning Portuguese at the time, I was trying to 
learn different European languages because I wanted to be a proper historian in Europe, and how can you do this if you don't know various European languages? And so I went to Bodleian Library and I got out this Casa Grande \&Senzala, I thought it was a very interesting book, because this is social-cultural history.

In 1961, this is still quite unusual in England, so I was fascinated. Then a few years later, I had my first job at the university in Sussex, and then in 1965 the university offered Gilberto Freyre a degree, honorary degree. I think they knew he was already in Europe getting an honorary degree in Germany, so they didn't have to pay his fare from Brazil. In any case, he came and they said the day before he got the degree, would he mind giving a lecture. So I went to this lecture he gave in English, very good English, and it was called The Racial Factor in Contemporary Politics, it's been published. And when Maria Lucia ${ }^{3}$ and I were writing the book, I went back and I read the lecture which I had originally heard, and this was very impressive, but also very amusing to me, because in the lecture he is talking about the value of miscigenação.

But he looked to me as if just purely Portuguese looking. And he was very pale, maybe because after a few weeks out of Brazil he was pale as unusual. So it seems that somebody who didn't look mixed at all was praising mixture. I couldn't meet him because I was too junior, so I wasn't invited to the party or the dinner that was given in his honor. I heard about him from Asa Briggs later, because Asa Briggs was a fan of Victorian literature, and Gilberto was a fan of Victorian literature, and to Asa's surprise, here was somebody coming from Brazil, and he could talk about all the Victorian novels he knew as much about as Asa Briggs did. So this was very... anyway, from that time, Gilberto Freyre was somebody that I knew about and was interested, I read Sobrados e Mucambos more or less that time as well, and I didn't go on to Ordem e Progresso partly because it looked such a fat book, and anyway, it was dealing with the XIX century, and at that point I was really limiting myself more to the earlier period.

And then nothing more happened until the year I was in Brazil as professor visitante no Instituto para EstudosAvançados in USP. So I didn't have any duties. I had this year, and I meant to continue work on the renaissance, but then I discovered - of course I suspected this before - the books available in USP, there were not very many dealing with this. The situation was worse than it is now because, as you may know,

\footnotetext{
${ }^{3}$ Maria Lúcia Garcia Pallares-Burke, his wife, is a Brazilian historian. She is a retired professor at the School of Education of the University of São Paulo (USP). She is an associate researcher at the University of Cambridge.
} 
USP doesn't have a central university library. All the different faculties have their own, and there was no general catalog. There is now, online, that makes life much simpler. So I just had to walk around the campus, and I would go into different faculties and look up the card catalog in that place. But I very quickly discovered, not really surprising, that they didn't have very much. So I thought it easier to adapt my research to the place where I am than to adapt this place to my research, so I'd work for this year on something Brazilian. So I think "well, I was interested in Gilberto Freyre".

Funnily enough, it wasn't the history faculty that had the most books. The place to go was the economics faculty. I think this is because the economics faculty has more money so they buy more books. Just as they have the best café and restaurant on campus, they have the best library on campus. And then I discovered what looked like an autobiography of Freyre, or his diary, which later Maria Lucia showed it was, in a way, not authentic, because although he publishes it saying this is what he thought in 1920, 1930, it was all revised later for publication, because she found a letter where he's writing to a friend, he says he's working on it. Which he shouldn't be, he should have just handed over the manuscript to the diary, but no. So it's very valuable for learning about him, but not necessarily at the dates that is in the diary.

But I thought I would do something a little different. I was very interested in the history of childhood. An important book for me was a book that Philippe Aries published in 1960 arguing that childhood, and the history, and that in a sense, in France, in the XVII century, children were painted as little adults by the time they were 7 years old. And I discovered that Gilberto was already interested in the history of childhood 40 years before Philippe Aries. And that he thought about writing a book about the child in Brazil, and characteristically, he would have included an account of his own childhood in this history, because he was a very egocentric person. Somehow he never did it. He got interested in Casa Grande. But buried in Casa Grande and in the later books, there are pages and pages about the history of childhood in Brazil. We could almost reconstitute a short book out of these bits.

So I thought... and I was invited to - I don't know how they heard that I was doing this - but that year I was already invited to Recife to one of the annual conferences on Gilberto Freyre. So I talked about him and the history of childhood, because how similar his kind of history was to the kind of history that was written by the Annales group in France. And it's also very interesting, it wasn't just the footnotes that Fernand 
Braudel wrote, and that's all I knew originally, but in 1943 Fernand Braudel wrote a whole article about the work of Gilberto Freyre, praising it enormously. And you can see the parallels between the French school and what Gilberto was doing here. Neither knew of the other at first, but he discovers them and they discover him, so that launched me on this kind of thing. And then when Maria Lúcia had finished working on XVIII century, first England and then the continent, and she was living in England, she began to think she'd like to write about Brazil. This is often what happens if you're out of your country, you reestablish a link by studying your country. She'd never been a brazilianist, always working on the history of Europe before. She was looking around for a subject, and so she thought "why not study the formation of Gilberto Freyre". So this is what particularly interested her: what kind of childhood did he have, how did he become the sort of actor that he eventually became. And so she wrote this book just about Gilberto before Casa Grande, and then afterwards we wrote together the book which was about the whole person. In fact, everybody normally writes about the author of Casa Grande, and very rarely do people write about the later Freyre. It's true it's not such an attractive subject, because he was brilliant when he was in his twenties, thirties and forties. And then it's never the same again: it's partly he's distracted, he had partly a political career, and so on.

He had been used to people thinking he was wonderful, but in 1964, the day after the establishment of the military regime here, he came out in favor, saying it was saving Brazil from communism. This is actually very curious, very, because in the 1930's, even in the 1940's, he'd be on the left. He was a friend of Jorge Amado, and he wrote in his defense once that he was an anti-anti-communist. He wasn't a communist himself, but he was an anti-anti-communist.

And there are caricatures in a newspaper in Recife, I forget which one, it wasn't the great Jornal de Pernambuco, Diário de Pernambuco, it was another paper. There's a caricature of him wearing an armband, and it has a hammer and a sickle on it. It was when he was running for the Assembleia Constitucional, I think. He got in all the same. But it's interesting. All the newspaper cuttings are there in the Fundação Gilberto Freyre, and we were working there for months when we were writing the book together. Gilberto's wife, Madalena, we met a few times. Simpática, mas formidável. She cut all the information about Gilberto from the newspaper, and it was all bound in black volumes, lots of volumes, because he was always in the newspapers. And if it was 
unfavorable, she had particular volumes - and this is very funny because on the volumes she wrote W.C. It's a kind of schoolgirl humor from somebody... Because she actually came from a quite aristocratic family, ex-plantation owners and all that, but still that was her kind of humor. And so in those volumes you could see the caricatures of him with this hammer and sickle. Anyway, for whatever reason, he never wrote the fourth volume he kept promising that he would write. Instead, he did a kind of popular sociology. It was interesting, he was trying to establish a specifically Brazilian sociology, but a lot of the time he is simply popularizing what north-American sociologists are doing. So I like the idea of the project, but I don't feel that he ever really executed it. Also, his character changes a bit, he becomes terribly vain. The last 20, 30 years of his life he is always dropping the names of famous people that he claims to know and so on. There's a revealing story, which I'm afraid might be true, that when Arnold Toynbee, who was famous at the time for his History of Civilization, he came to Recife, and Gilberto thought it was to visit him! But no, it was to visit HélderCâmara, so Gilberto was really disappointed. He was the sort of person who would assume that if a distinguished foreigner comes to the city there could only be one reason, it could only be to see him. Only, of course, it wasn't like that.

Question: In A Social History of Knowledge Volume II: From the Encyclopedie to Wikipedia, you approach the importance of the periodical press to spread scientific knowledge, bringing specific concepts from different areas of academic education to daily life and making them palatable. How do you evaluate the role of these publications today, their impact, and their ability to dialogue with a vast audience?

Peter Burke: I think the golden age of the intellectual journal was the XIX century. There were so many in England, in particular, Edinburgh Review, Westminster Review and so on, but also in France, Revue de Deux Mondes, and so on. There's nothing quite like that today. The nearest thing in England in my time was Encounter. This journal, it was always clear it was a bit conservative, but it included new short stories, that was how Borges was first published in English. Serious discussions, but short ones, of the arts, of literature, of politics, economics, and so on. Not the natural sciences. That's one difference from the XIX century. Encounter was only appealing to one of the two cultures, in that famous distinction which is commonplace in England, I don't know whether it is elsewhere; this chemist-turned-novelist, Charles Snow, he gave a famous 
lecture in Cambridge where he complained that the country, or the elite of the country, had been divided into two cultures: the scientists and the humanists, and nobody with a literary education had any idea what the second law of thermodynamics was and that's terrible, that people should know about science. And this would never have been true in the XIX century; say, George Eliot wrote for the Westminster Review before she discovered her talent as a novelist. And she had a very good knowledge of the natural sciences as well as of the arts, and that was normal in Victorian times. So I'm saying really that Encounter, which was the nearest thing to what you're talking about, was still limited to the arts and social sciences. And then it was discovered that the CIA was subsidizing the publication, and people stopped buying it and it collapsed. After that, in Britain, there's only the Times Literary Supplement and the London Review of Books, and they are much more about literature than anything else, so they were not doing this general job of informing an educated public about everything, it's just about literature really, a bit of history. Specializations go on further and further, so there are plenty of good journals dealing with a particular subject. But this attempt to inform general educated people about a whole range of disciplines, that has disappeared. And this is something I have to discuss in the new book about polymaths, and how it is possible for just a few people to survive in this world of ever increasing specialization.

Question: Still regarding this book: did the internet, as a memory space, make knowledge more difficult to hide, destroy, and discard? You talked a little about this yesterday.

Peter Burke:Yes, and the digital revolution generally, because archives now, and libraries, are putting their material into this form as well as in the original form. Well, sometimes this is more worrying, and they destroy the original after they put it online, and then there's the question we don't really know yet: how, in 50 years' time, will this stuff still be retrievable. So that's another problem. But definitely, putting a whole archive on the internet, this could sometimes have very valuable consequences. I have a friend who works on Spain in the XVI and XVII centuries, and he has this terrible muscular dystrophy, now he lives in the United States, but getting on a plane and going to Spain to work in the archives has become very difficult for him. But every day he turns on his computer and he starts to search the archives online, so he can still do good work. So that's a positive side of it. Your question was about the positive side. 
Question: You say that many great scholars never went to the archives, but were excellent on analyzing data collected by others. How do you distinguish these roles and the importance of these two activities, or moments, of the research process - going out to the archive and examining data?

Peter Burke: What's important for historians, and other scholars working on the past, is the sources. It's not relevant, in my view, whether the sources are in print or in manuscript, they are still the sources. And if the sources in print are very rich, and if you want to write a rather general book, I think there's really no point in going to the archive. Check the example of Jacob Burckhardt, who wrote the greatest book about the Italian renaissance, and he never went near an archive. But there was a mass of material from the XV and XVI centuries in print and he studied it, so he wrote the book from the sources. One mustn't make a fetish of the archives.

Other topics, there's almost nothing in print, so if you want to study it, you have to spend all your time in the archive. So I wrote my first book about Italian renaissance and I didn't go to the archive, and there was even more in print than in Burckhardt's time. But then, for the second book I thought "I have to find out what this experience of archives is like, so I'm going to choose a topic where it's absolutely essential'. So I wrote this book about the elite of Venice and Amsterdam in the XVII century. So first, I went and spent months in the Venetian archive for the first part of the book, and then I went to Amsterdam and did the same thing in the Dutch archives. And most of the time, the only difference is you're reading and writing. In the case of Venice, luckily, there's no problem reading and writing because, thanks to the renaissance, people were writing in a very clear hand, which is not at all unlike this. In the Dutch archive it was much more difficult, because in the XVI century it was like the Germans, they were writing in this kind of gothic hand. The first day I saw something in it, couldn't read a single word. But I was working on the XVII century end, so that means it's nearly the XVIII, so the very end. So I thought 'I'll start at the wrong end, because then people wrote in an XVII century handwriting, which is very easy to read". Then I got used to the shape the documents were in, and then I went back to the earlier ones and it was much easier to decode, because I was beginning to know what to expect. Anyway, the most interesting thing is sometimes they bring you the wrong file, or sometimes the material in the file is not the interesting part, is not the part that you knew about, which is why 
you ordered it, but something else that is in the same package. So the thrill of the archive is the thrill of discovering something totally different. It's a bit like gambling. You order something and you don't really know what's in it, it could be very good for you, and it could be totally useless. So it's got its charm, but still, I think, historians who begin in the archives, you feel that they look down a bit on what they call library historians. But it's a false opposition, really, we all want to study the sources. The crucial thing is to find the right sources for the particular problems you're doing. So the last time I worked in archives was in the Fundação Gilberto Freyre. Working in the archives really meant reading the letters he received, which, often times, there was no problem. And best of all was picking up all his books and seeing what he wrote in the margins. Luckily, reading his handwriting is not a problem. We could have been unlucky and chosen somebody to work on who had horrible handwriting, but no, we were lucky.

Submetido em: 12.04 .2018

Aprovado em: 14.06.2018 